UDK 532.5:519.86:556.182:556.3:631.621

Olexandr O. Diatel, Research Associate

ORCID ID: 0000-0002-1258-7561e-mail:alexandr_dyatel@ukr.net

Institute of Water Problems and Land Reclamation of the National Academy of Agrarian Sciences of Ukraine, Kyiv, Ukraine

\title{
CALCULATIONS AND PROGNOSIS OF THE INFLUENCE OF THE EXPLOITATION OF THE "HOTYSLAVSKE" QUARRY ON THE HYDRODINAMICS OF THE GROUND AND UNDERGROUND WATERS OF THE WESTERN POLISSYA
}

\begin{abstract}
The problems of the influence of the exploitation of the deposit of the sand and chalk "Khotislavske" on the hydrodynamics of ground and underground waters of Western Polissya are considered. At this the analytical methods of calculation of geophiltration processes and methods of mathematical modeling were used. The analysis of the validity of forecast calculations and modeling of the influence of a quarry on the territory of Ukraine carried out by the Belarusian side and the comparison of data are carried out.

Key words: filtration area; infiltration recharge; water inflow; hydrogeological conditions; overdraining; technogenic conditions.
\end{abstract}

\section{Introduction}

The development of the deposit of building materials "Hotislavske" on the territory of the Republic of Belarus for many years has been the subject of discussions on its possible impact on the adjoining territory of Ukraine.

This problem was particularly acute when known specialists and specialists came to the conclusion that is the real possible negative impact of the quarry development on the territory of Western Polissya including the territory of the Shatsk National Park.

Taking into account the aforementioned, the problem of quantitative assessment of the transboundary impact on the territory of Ukraine on the development of this field for the long-term period of its exploitation was raised.

\section{Analysis of recent researches and publications}

In the process of the investigations the hydrogeological conditions of the territory of Western Polissya and the conditions of the formation of water resources of the zone of active water exchange the hydrological conditions, the state of surface water courses including the reclamation facilities and the modern water and ecological status of a certain territory were analyzed and determined.

In addition on the base of the analysis of the hydrodynamic conditions of the main aquifers and the filtration schemes of the ground and underground waters interactions in the given area have been developed which allowed to create a conceptual model for water exchange of surface and groundwaters.

When creating the model the results of the modeling of the impact assessment on the environment of the Khotilaslavske field development which are presented in the

(C) O.O. Diatel, 2018 
corresponding Report of the Belarusian side [13] and monographs [2, 14], were used and analyzed. It was shown that the results of the impact can be considered approximate in connection of with the insufficient reliability of the used data by the Belarusian specialists.

The purpose of the research is to evaluate the impact of the development of the sand and chalk deposit "Khotilslavske" (Republic of Belarus) on the hydrogeological and hydroecological conditions of the territory of Ukraine within the Western Polissya, including the territory of the Shatsk National Park.

In this case the analytical methods of calculation of processes of geophylration and methods of mathematical modeling were used. In addition the analysis of the validity of the projected calculations and modeling the impact of a quarry on the territory of Ukraine performed by the Belarusian side and the comparison of data has been carried out.

\section{Research results}

The research area is characterized by complex hydro-geological conditions and is not well understood especially in the north-western part where the Kopayevsk drainage system is located $[14,2]$.

Absence of reliable data on the separate areas of the determined territory predetermines the approximate approach to the calculations and forecasting of the impact of the operation of the quarry on the hydrodynamics of the ground and underground waters of Western Polissya within its possible influence (Figure 1), which is also noted in the Report of the Belarusian side [13].

Water intake to the quarry is formed at the expense of natural resources of the main aquifers and atmospheric precipitates and at the hydrodynamic schematization it can be considered as a radial flow to a well with a large diameter in an unbounded area of filtration with the assignment on the contour of the quarry the corresponding boundary conditions (values of water intake or constant drawdown on the contour of the quarry).

Proceeding from the foregoing one can consider the problem of water inflow to a large diameter well in a three-layer aquifer unbounded in plane with the absence of flowing from below aquifer and with infiltration recharge $[6,12]$.

In the assumption of a rigid regime of filtration in a weakly permeable distribution layer of the colmatation zone of the marl-chalk layer and the failure to take into account the infiltration feed of the ground stream the process of transient filtration can be described by the following system of differential equations in partial derivatives [12]:

$$
\begin{aligned}
& a_{1}\left(\frac{\partial^{2} S_{1}}{\partial r^{2}}+\frac{1}{r} \cdot \frac{\partial S_{1}}{\partial r}\right)-b_{1}\left(S_{1}-S_{2}\right)=\frac{\partial S_{1}}{\partial t} \\
& a_{1}\left(\frac{\partial^{2} S_{2}}{\partial r^{2}}+\frac{1}{r} \cdot \frac{\partial S_{2}}{\partial r}\right)+b_{1}\left(S_{1}-S_{2}\right)=\frac{\partial S_{2}}{\partial t}
\end{aligned}
$$

where $\quad a_{1}=T_{1} / \mu_{1}, \quad a_{2}=T_{3} / \mu_{2}, \quad b_{1}=K_{2} / \mu_{1} m_{2}, \quad b_{2}=K_{2} / \mu_{2} m_{2} ;$ $S_{1}(r, t)=H_{o i}-H_{i}(r, t)$ - the drawdowns of levels and heads in aquifers with water 
permeabilities $T_{1}=k_{1} m_{1}, T_{3}=k_{3} m_{3} ; H_{o i}$ and $H_{i}(r, t)$ - levels and heads before and during the water uptake process $(i=1,2) ; \mu_{1}$ and $\mu_{2}$ - coefficients of storativity of water-bearing horizons.

The system of equations (1) is solved under the following boundary conditions:

$$
\begin{aligned}
& t=0, S_{1}=S_{2}=0 \\
& t>0, r \rightarrow 0,2 \pi T_{1} \frac{\partial S_{1}}{\partial r} \rightarrow-Q, \frac{\partial S_{2}}{\partial r}=0 \\
& t>0, r \rightarrow \infty, S_{1} \rightarrow 0, S_{2} \rightarrow 0
\end{aligned}
$$

where $t$-hour, day; $r$ - coordinates in space and $Q$ - constant water uptake from the well.

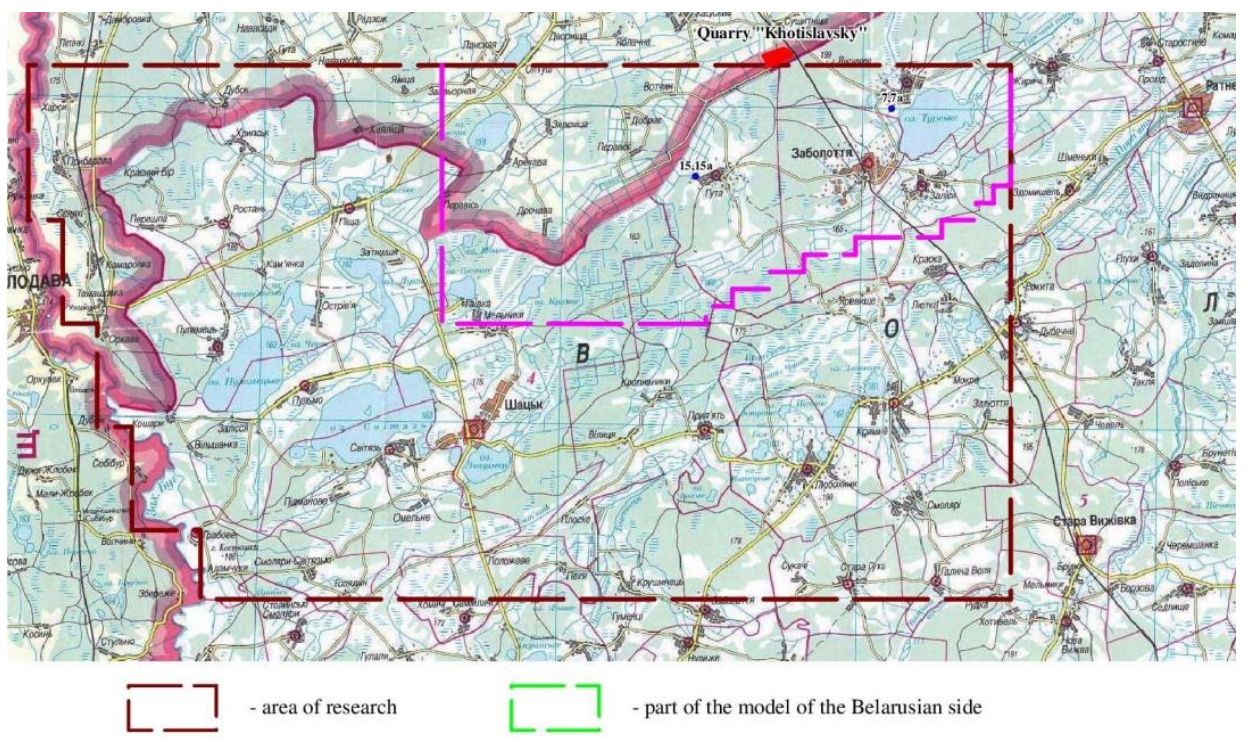

Fig. 1 - Selected area of research within the territory of Western Polissya. Scale 1:200 000. Note. Within the research area a part of the model of the Belarusian side is demonstrated

The general analytical solution of this problem was received with a help of integral transformations which has the following form with respect to the drawdowns $S_{1}(r, t)$ and $S_{2}(r, t)[12]$ :

$$
S_{i}(r, t)=\int_{0}^{\infty} p j_{0}(p r) S_{i} \cdot(p, t) d t
$$

Equation (3) is a complex analytic expression which can only be realized in a numerical way. To do this an appropriate software package was developed and special tables of filtration resistances for multilayer filtration schemes were designed which greatly simplify the calculations and simulation of the problems of the given class $[7,12]$. 
It is known that in practical calculations the process of interconnection of aquifers through weakly permeable layers during water uptake from one of the horizons can be divided into several stages, namely $[6,7,12]$ :

1. small times when the magnitude of the drawdown in the adjacent horizon is insignificant and mainly in the horizon from which the water uptake takes place one can consider the filtration according to the scheme of the isolated water-bearing layer; 2. intermediate times when the flow from the adjacent horizon begins; 3. intermediate large times when there is an uneven drawdown in levels and heads in both horizons; 4 . The time when the magnitude of the drawdown can be calculated according to the scheme of a single-layer formation with integral parameters of the whole water-bearing thick:

$$
S_{1}(r, t)=S_{2}(r, t)=\frac{Q}{4 \pi T} w(u)
$$

where $T=T_{1}+T_{3}, \mu=\mu_{1}+\mu_{2}, a=T / \mu, w(u)$-function, $u=r^{2} / 4 a t$.

For small times the expression for calculating the time criterion of the well operation in the scheme of a single-layer formation has the following form [7]:

$$
t_{1} \leq 0.01 \mu_{1} m_{2} / K_{2}
$$

Substituting the data on the aquifer of the quaternary deposits in the area of the quarry $\mu_{1}=0.2, m_{2}=10.0 \mathrm{~m}, K_{2}=5 \cdot 10^{-3} \mathrm{~m} /$ day, we find that $t_{1} \leq 4$ days that is the water uptake from the quarry is provided of only from the horizon of groundwater during 4 days after which the interaction with the lower horizon in the marl-cretaceous strata begin because of the flow from the bottom to the top.

Since according to project decisions [13] the production of chalk and sand from a quarry is planned until 2040 that is for 30 years starting in 2009 when the development of the first stage of the deposit began it is interesting to calculate the time criterion after which the water uptake from quarry can be modeled according to the scheme of a single-layer formation with integral parameters of the entire aquifer. For this case the following dependence is recommended [7]:

$$
t_{1} \geq 20 B^{2} / a_{2}, r / B \geq 5
$$

where $B$ - flowing parameter, $\mathrm{m} ; a_{2}$ - piezotransmission coefficient, $\mathrm{m}^{2} /$ day.

Substituting the data for the quarry area taken from the model of the Belarusian side we obtain that $B=419 \mathrm{~m}$. At $a_{2}=1.3 \cdot 10^{4} \mathrm{~m}^{2} /$ day, $t_{2} \geq 270$ days that is after 270 days the system of aquifers can be considered as the only one aquifer with integral parameters of the whole water-bearing thick.

As a rule at calculations of quarry drainage one operates the concepts of working out of depth of a quarry with the corresponding drawdowns of the levels of ground water in it. Forecasting relative to drawdowns is more reasonable than the designation of drainage design values in a quarry as in the development of deposits the determination of drainage values is more approximate in comparing with the 
calculations of the distribution cone of depression with a constant drawdown in the career contour.

Taking into account the accepted schematization of hydrogeological conditions in cross section of the research area the following dependence was used to determine the impact of the development of a quarry on the level regime of groundwater $[1,9]$ :

$$
S(r, t)=S_{0} \cdot A(\tau, \rho)
$$

where $S(r, t)$ - the magnitude of the drawdown at the time $t$ at a distance $r$ from the quarry; $r_{0}$ - radius of a "big well" that is a career, $\mathrm{m}$; $S_{0}$ - the design value of drawdown of the level of groundwater at a water uptake, $\mathrm{m} ; A(\tau, \rho)$ - special tabulated function; $\tau=a t / r_{0}^{2} ; \rho=r / r_{0}$.

The advantage of using this model is that the calculation of drawdowns is taken from existing levels of ground water in which the infiltration takes into account and for long-term forecasts this assumption is justified [9].

Since in the modeling results of the Belarusian side the values of the design drawdowns of $12.0 \mathrm{~m}$ are appeared in the development of the first stage of the deposit and $45.0 \mathrm{~m}$ with its further development by 2040 a simulation of the distribution of changes in groundwater levels for the project period from the beginning of the development (2009) until 2040 at $\mathrm{S}_{0}=12.0$ and $\mathrm{S}_{0}=45.0 \mathrm{~m}$ based on the dependence (7) was performed.

Data of numerical simulation at different distances from a quarry at $\mathrm{S}_{0}=12.0 \mathrm{~m}$ are given in Table 1.

Table 1 - The magnitude of the drawdowns of the groundwater levels in the research area based on the results of numerical simulation at $S_{0}=12.0 \mathrm{~m}$

\begin{tabular}{|c|l|c|c|}
\hline \multirow{2}{*}{$\begin{array}{c}\text { № } \\
\text { n/a }\end{array}$} & \multicolumn{2}{|c|}{$\begin{array}{c}\text { Distance from the career, } \\
\mathrm{km}\end{array}$} & \multicolumn{2}{|c|}{$S_{0}=12.0 \mathrm{~m}$} \\
\cline { 3 - 4 } & \multicolumn{1}{|c|}{$\begin{array}{c}2016-2025 \mathrm{y} \cdot \mathrm{y} ., \\
t=10 \text { years }\end{array}$} & $\begin{array}{c}2016-2040 \mathrm{y} . \mathrm{y} ., \\
t=25 \text { years }\end{array}$ \\
\hline 1. & lake Svyate, 6.0 & $2.02 \mathrm{~m}$ & $3.08 \mathrm{~m}$ \\
2. & village of Guta, 7.0 & $1.62 \mathrm{~m}$ & $2.6 \mathrm{~m}$ \\
3. & settlement of urban type & $1.62 \mathrm{~m}$ & $2.6 \mathrm{~m}$ \\
& Zabolotya,7.0 & $1.48 \mathrm{~m}$ & $2.55 \mathrm{~m}$ \\
4. & lake Velikhovo, 7.2 & $1.35 \mathrm{~m}$ & $2.38 \mathrm{~m}$ \\
5. & reservoir Turske, 7.6 & $0.73 \mathrm{~m}$ & $0.99 \mathrm{~m}$ \\
6. & village Zalisy, 10.0 & $0.23 \mathrm{~m}$ & $0.85 \mathrm{~m}$ \\
7. & village Yarevishche, 14.4 & $0.115 \mathrm{~m}$ & $0.60 \mathrm{~m}$ \\
8. & Pripyat River, 16.4 & - & $0.5 \mathrm{~m}$ \\
9. & lake Krymno, 17.2 & - & $0.17 \mathrm{~m}$ \\
10. & settlement of urban type & - & $0.1 \mathrm{~m}$ \\
& Ratne, 23.4 & & \\
\hline 1. & lake Liutsymer, 25.6 &
\end{tabular}

Based on the results of the simulation the graphs of groundwater levels drawdowns in dependence of the distance from the quarry to the area of possible influence on the given periods of time were building (Figures 2-3). 
As can be seen from Table 1 and from the corresponding graphs of the drawdowns the potential impact reaches the Pripyat river by 2025 where a drawdown of $S=0.115 \mathrm{~m}$ is forecasted. The radius of influence will be more than $16 \mathrm{~km}$. The zone of influence will include lakes Svyate, Velychovo, Tursk reservoir and a significant number of settlements of the border with the territory of Belarus.

The levels of water in the lakes of Svyate and Velickovo will decrease respectively by 2.02 and $1.62 \mathrm{~m}$ at the existing depth of the lake Svyate $15.0 \mathrm{~m}$ that is the depth of the lake can be reduced by about $2 \mathrm{~m}$. As for the reservoir of Tursky at its depth of $2.0 \mathrm{~m}$ a decrease of $1.35 \mathrm{~m}$ will practically change its hydrological regime $[14,5]$. In addition the drawdowns of ground water levels in the impact zone by $0.5-1.5 \mathrm{~m}$ will worsen the water supply conditions of the population living in this area.

A more difficult situation may arise as of 2040. The impact of quarry development will be of a regional level. The radius of influence will be more than $29 \mathrm{~km}$ reaching the territory of Shatsky lakes (Fig. 1). So the water level in the lake Lutzumer is projected to be $0.1 \mathrm{~m}$ below the current one that is all lakes of Shatsk National Park will fall into the zone of influence.

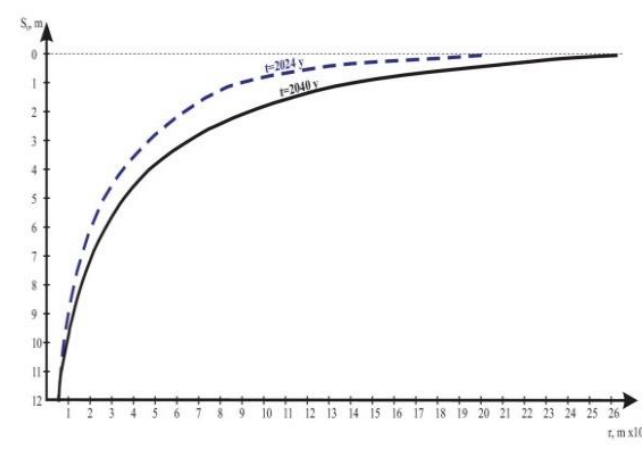

Fig. 2 - Charts of the dependence of the ground water level drawdown from distance to quarry with constant level on its contour $\mathrm{S}_{0}=12.0 \mathrm{~m}$ by 2024 and for 2040 years of working out of a quarry

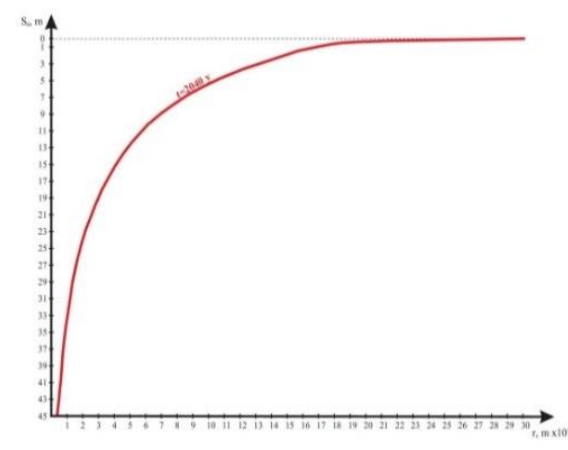

Fig. 3 - Chart of the dependence of the ground water level drawdown rom distance to a quarry with a constant level on its contour $\mathrm{S}_{0}=45.0 \mathrm{~m}$ by $2040 \mathrm{y}$ quarry development

For the purpose of the comparison with the Belarusian side's forecast solutions for 2040 at $S_{0}=12.0 \mathrm{~m}$ a schematic map of the influence of the development of a quarry on the level regime of groundwater on a scale of 1: 200000 was constructed (Fig. 4). As can be seen from the map the magnitudes of the drawdowns differ significantly among themselves and the distribution of the impact zone according to the modeling of the Belarusian side by 2040 to some extent coincides with the data of the calculations performed at $S_{0}=12.0 \mathrm{~m}$ on 2025 taking into account and without compensatory measures to decrease the zone of influence on the territory of Ukraine. Thus even with the development of only the upper part of the quarry cross section the projected impact will cover a significant territory of Ukraine.

The next stage in the assessment of the impact of the exploitation of the quarry was the simulation of the drawdowns of groundwater levels by 2040 with the designation on the quarry contour a constant value of drawdown $S_{0}=45.0 \mathrm{~m}$ for a 
period of 15 years from 2025 to 2040 according to design decisions for the development of this deposit [3,13].

The choice of the modeling period from 2025 to 2040 at $\mathrm{S}_{0}=45.0 \mathrm{~m}$ is due to the assumption that by 2025 the second queue of the quarry will start working as there are no exact dates for the introduction of the second stage in the reporting materials of the Belarusian side. At all forecasting maps for 2014, 2019, 2024 and 2040 the isolines of drawdowns are given at $\mathrm{S}_{0}=12.0 \mathrm{~m}$ (Fig. 4), only one of the maps shows the plane propagation of groundwater levels drawdowns at $S_{0}=45.0 \mathrm{~m}$ but on state of 2014 year. These data of the drawdowns of the groundwaters are not trustworthy since according to the monitoring data of the Belarusian side in 2014 only the upper part of the cross section of the quaternary sediments was developed with drainage of $1500 \mathrm{~m}^{3} /$ day in $2009,1200 \mathrm{~m}^{3} /$ day in $2013,7176 \mathrm{~m}^{3} /$ day in 2015 and $8836 \mathrm{~m}^{3} /$ day in $2016[10,11]$.

For specify of the obtained data we have carried out calculations of groundwater level drawdowns in the territory adjacent to the quarry by the end of 2009, 2013, 2015 and 2016 according to the data of the Belarusian side on the drainage using on the dependence (4). Thus for 2009 at $\mathrm{Q}=1500 \mathrm{~m}^{3} /$ day the drawdown on the contour of the quarry was about $1.8 \mathrm{~m}$ and about rs. Tursk (observation wells 7 and 7a, Fig. 1) the influence is absent, $\mathrm{S}<0.1 \mathrm{~m}$ ). As of 2013 at $\mathrm{Q}=1200 \mathrm{~m}^{3} /$ day the drawdown on the contour of the quarry was about $1.95 \mathrm{~m}$ and in the vicinity of observation wells 7 and $7 \mathrm{a}$ - about $0.1 \mathrm{~m}$; as of 2015 at $\mathrm{Q}=7176 \mathrm{~m}^{3} /$ day the drawdown was $12.4 \mathrm{~m}$ while near the Turske reservoir was $1.2 \mathrm{~m}$; as of 2016 at $\mathrm{Q}=8354.7 \mathrm{~m}^{3} /$ day the drawdown is calculated $\mathrm{S}=14.8 \mathrm{~m}$ and in the area of the reservoir Tursk - about $1.4 \mathrm{~m}$.

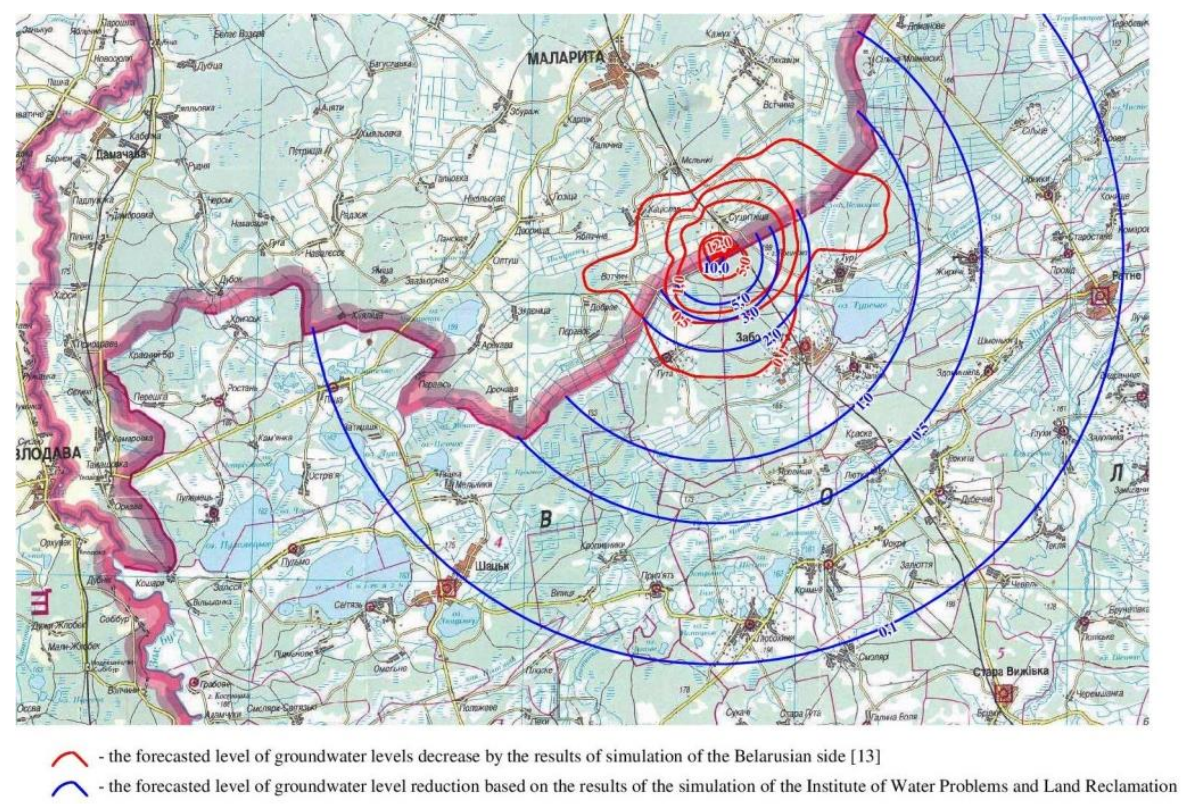

Fig. 4 - The map of forecasted ground water levels drawdowns on the research area by 2040 with a constant drawdown on the quarry contour $S_{0}=12.0 \mathrm{~m}$

Similar calculations were carried out at a distance of $7.0 \mathrm{~km}$ (Huta village) where observation wells 15 and 15a (Fig. 1) are located. 
The analysis of the calculation data and the data of the observation wells indicates that there is a sufficient agreement between the data of calculations and regime observations as both regime data and estimated data show almost the same drawdowns in groundwater levels at a distance of 7.0-7.6 km from the quarry on 2016 year.

The comparative characteristic of the obtained data allows us to assert that for the accepted schematization of the technogenic conditions in the zone of possible influence of the operation of the quarry the indicated calculation models are reasonably reflect the process of changes in water exchange on the territories adjacent to the quarry.

In order to assess the possible impact of the development of a quarry with the full development of its on 2040 year with a design drawdown of $S_{0}=45.0 \mathrm{~m}$ an appropriate numerical modeling of the distribution of influence on the basis of dependence (7) was conducted. Data model calculations are given in Table 2.

Table 2 - Data on groundwater level drawdowns in the research area by numerical simulation results at $\mathrm{S}_{0}=45.0 \mathrm{~m}$

\begin{tabular}{|c|l|c|}
\hline $\begin{array}{c}\text { № } \\
\text { n/a }\end{array}$ & \multicolumn{1}{|c|}{ Distance from the career, $\mathrm{km}$} & $\mathrm{S}_{0}=45.0 \mathrm{~m}, \mathrm{t}=2040$ year \\
\hline 1. & lake Svyate, 6.0 & $10.37 \mathrm{~m}$ \\
2. & village of Guta, 7.0 & $8.86 \mathrm{~m}$ \\
3. & settlement of urban type Zabolotya, 7.0 & $8.86 \mathrm{~m}$ \\
4. & lake Velikhov, 7.2 & $8.46 \mathrm{~m}$ \\
5. & reservoir Turske, 7.6 & $7.96 \mathrm{~m}$ \\
6. & village Zalisy, 10.0 & $2.97 \mathrm{~m}$ \\
7. & village Yarevishche, 14.4 & $2.48 \mathrm{~m}$ \\
8. & Pripyat River, 16.4 & $1.5 \mathrm{~m}$ \\
9. & lake Krymno, 17.2 & $1.43 \mathrm{~m}$ \\
10. & settlement of urban type Ratne, 23.4 & $0.39 \mathrm{~m}$ \\
11. & lake Liutsymer, 25.6 & $0.2 \mathrm{~m}$ \\
12. & lake Svityaz, 25.8 & $0.19 \mathrm{~m}$ \\
13. & village Khripsk, 29.0 & $0.09 \mathrm{~m}$ \\
\hline
\end{tabular}

According to this simulation a map of the depression distribution was constructed in the definite area of research for the forecast period of 2040 (Fig. 5).

The obtained data indicate that the zone of possible influence with full development of a quarry practically covers the entire study area within a radius of $29.0 \mathrm{~km}$. The influence will extend also and in the eastern direction beyond the investigated filtration area on the same distance (Fig. 1, 5).

As can be seen from Table 2 the influence of a quarry reaches in the 2040 year the group of Shatsky lakes. On the territory of Shatsk National Park the groundwater levels will decrease from 0.1 to $0.2 \mathrm{~m}$ on average.

If you compare the estimated values of the drawdowns with the depths of individual lakes then it is predicted that, for example, the depth of the lake Svyate will decrease by $10.0 \mathrm{~m}$ relatively the present depth of $15.0 \mathrm{~m}$, the depth of the lake Liutsymer will decrease by $0.2 \mathrm{~m}$ at the present $11.2 \mathrm{~m}$, the depth of the lake Krymno will decrease by $1.43 \mathrm{~m}$ with the existing $6.0 \mathrm{~m}$, lake Luky at $0.7 \mathrm{~m}$ with existing $3.5 \mathrm{~m}$, lake Svityaz with 0.2 at existing $58.4 \mathrm{~m}$. As all lakes are hydraulically connected their hydraulic regime will change significantly and the lakes with small 
depths located in the zone of the influence where the forecast drawdowns will be of the order of 3-10 $\mathrm{m}$ will be practically on the verge of drying out.

A similar picture should be expected regarding the river network. Taking into account the fact that almost all watercourses in the territory are characterized by insignificant depths, for example, the depth of the Pripyat River near village Ritchitsya is $2.73 \mathrm{~m}$ and higher along the channel the depth is yet smaller, the depth of the Vyzhivka River near the village Vyzhivka is $0.97 \mathrm{~m}$ it is possible that there will be drying out of all rivers. Gradually instead of the drainage function the river system will turn into a groundwater recharge area whose drawdowns of the levels will result in an increasing of the thickness of the aeration zone and the drying of the main aquifer.

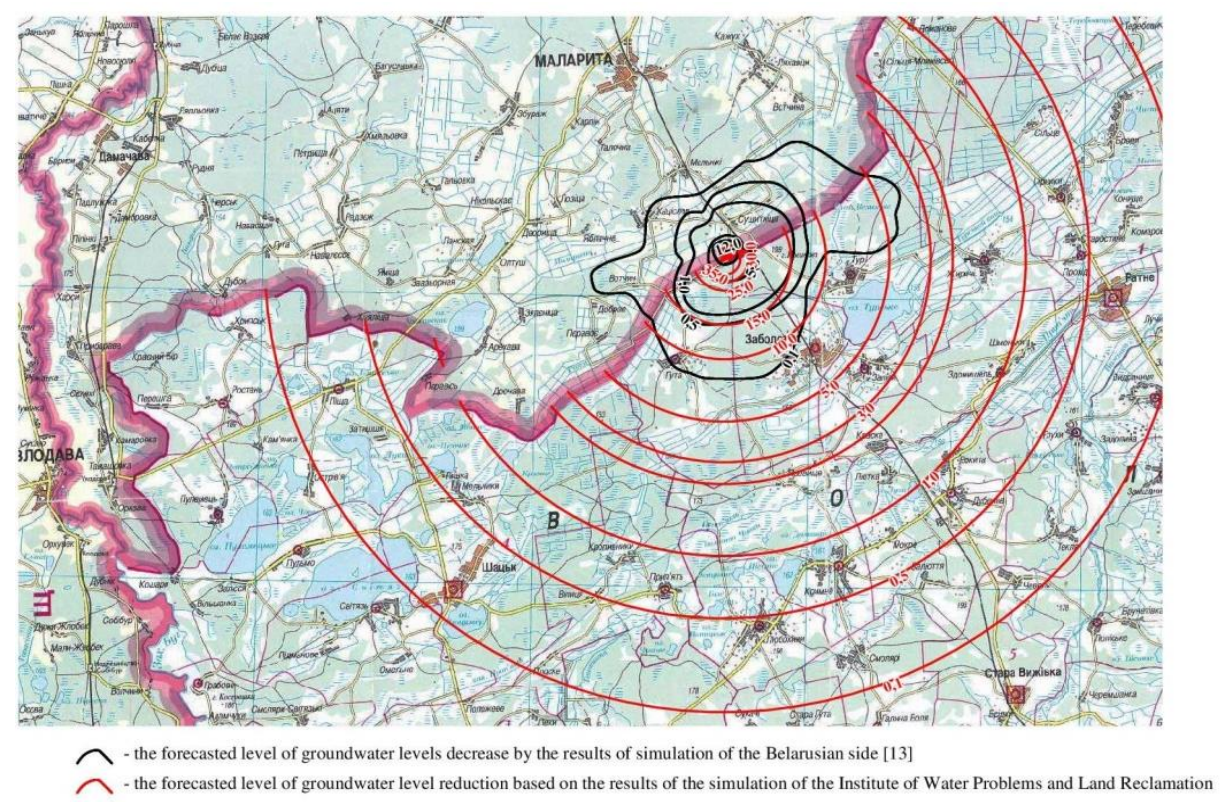

Fig. 5 - Mapping of forecasted drawdowns of the groundwater levels in the research area by 2040 with a constant drawdown on the contour of the quarry $S_{0}=45.0 \mathrm{~m}$

Khotyslavsky quarry with hydrodynamic schematization can be considered as a separate field which drains aquifer complex of ground and underground waters. In the conditions of the steady filtration in the unbounded water aquifer in the plan the water inflow to the quarry by 2040 can be calculated according to the following dependences $[9,12]$ :

$$
Q=\frac{2 \pi T S_{0}}{\ln \left(\frac{R}{r_{0}}\right)}
$$

where $T$ - coefficient of the permeability of the complex, $T=420 \mathrm{~m}^{2} / \mathrm{day}$;

$S_{0}=45.0 \mathrm{~m}$;

$R$ - radius of influence in the field of filtration, $R=29.0 \mathrm{~km}$;

$r_{0}$ - quarry radius, $r_{0}=400.0 \mathrm{~m} \mathrm{[14]}$. 
Substituting the given data into (8) we obtain that $Q=27732 \mathrm{~m}^{3} /$ day that is for the conditions of ensuring of the lateral recharge of the complex the designed drainage from the quarry is almost equal to the quantity of the water inflow. Taking into account the fact that the recharge of the aquifer system will decrease due to precipitation and in order to ensure water inflow to the quarry the area of the impact of its will be expanded changing the water balance within the entire area of distribution of the aquifer complex $[2,15,16]$.

It should be noted that in the forecast period the water withdrawal from the aquifer system will also increase for water supply of the population with drinking water. In total it is planned to increase the water withdrawal to 50 thousand $\mathrm{m}^{3} /$ day and in general taking into account the drainage from the quarry the water uptake will increase to 70-75 thousand $\mathrm{m}^{3} /$ day [13].

Thus the carried out numerical-analytic calculations and simulations have shown that the development of the Khotsyslavske sand and chalk deposit for the projected period of operation by 2040 will significantly change the hydrodynamic conditions in the territory of Western Polissya and in general will aggravate the hydrogeological and ecological situation in the defined territory.

\section{Conclusion}

According to the results of numerical simulation for the 1st stage of quarry development at $S_{0}=12.0 \mathrm{~m}$ it follows that by 2025 the potential impact will reach the Pripyat River where the decreasing of the groundwater levels is expected to be $\mathrm{S}=0.115 \mathrm{~m}$. The radius of influence will be more than $16 \mathrm{~km}$. The zone of influence will include the lakes Svyate, Velychovo, Tursk reservoir and a significant number of settlements within of the border with the territory of Belarus.

A more difficult situation may arise in the development of the second stage with a drawdown of $45 \mathrm{~m}\left(\mathrm{~S}_{0}=45.0 \mathrm{~m}\right)$ by 2040 . The impact of a quarry development will be of a regional character. The radius of influence will be more than $29 \mathrm{~km}$ reaching the territory of Shatsky lakes. The influence will spread and in the eastern direction beyond the investigated filtration area.

In addition the conclusions of the Belarussian specialists that the development of the stated quarry will not influence on the territory of the Shatsky lakes are doubtfully as in the Belarusian model this area is not included.

On the whole the comparative characteristics of the obtained data allows to suggest that for the schematized technogenic conditions in the zone of possible influence of the exploitation of the quarry the indicated calculation models are reasonably reflect the processes of the changes in the water exchange on the adjacent to the quarry territories.

\section{REFERENCES}

1. Bochever F. M., Garmonov I.V., Lebedev D. V., Shestakov V. M. Fundamentals of hydrogeological calculations. Moscow: Nedra, 1965. $250 \mathrm{p}$.

2. Zaleskiy I.I., Zuzuk F.V., Melnychuk V.G., Matejuk V.V. Shatskoe overlake Geological structure and hydrogeological conditions. T.1. Lutsk: Eastern European National University, 2014. $188 \mathrm{p}$.

3. Statement on the impact on the environment of the planned economic activity "Development of a chalk deposit " Hotislavskoe "(Phase II) in the Malorita district of the 
Brest region". Minsk: Kvartstelprom, RUE TsNIIKIVR, State Scientific and Production Association "NAS of Belarus on Bioresources", 2009. 12 p.

4. Zuzuk F.V. Probability of influence of development of Khotilaslavskogo deposit of chalk on reserve ecosystems of Volyn. Zb sciences Works "Nature of Western Polissya", Lutsk, SNU by name Lesia Ukrainka. 2016. No. 9. P. 3-11.

5. Ilyin L.V. Volyn Lakes: Limnogeographical characteristic. Luck: Nadstyr'ya, 2000. 140 p. 6. Lomakin E.A., Mironenko V.A., Shestakov V.M. Numerical simulation of geophyltration. Moscow: Nedra, 1988. 228 p.

7. Methodical recommendations on calculations of protection of territories from flooding in the irrigation zone. Kiev: Ministry of Water Resources of the USSR, 1986. 392 p.

8. Mokryy V.I. Monitoring, modeling and forecasting of the influence of Khotilaslav's quarry on the hydrogeological and forest-ecological conditions of nature reserves of Western Polissya. Zb sciences Works "Nature of Western Polissya and adjoining territories", Lutsk, SNU them. Lesia Ukrainka. 2012. No. 9. P. 284-288.

9. Norvatov Yu.A. The study and forecast of the technogenic regime of groundwater. Leningrad, Nedra, 1988. $261 \mathrm{p}$.

10. About monitoring in the area of the Khotilslavskoe field. Letter of the Ministry of Natural Resources of the Republic of Belarus to the Ministry of Ecology and Natural Resources of Ukraine dated July 24, 2017 for No. 3-10 / 36 - imo. Minsk, 2017. 12 p.

11. About monitoring in the area of the deposit of sand and chalk "Hotislavskoe". Letter from the Ministry of Natural Resources and Environmental Protection of the Republic of Belarus. Minsk: No. 13-11 / 3536-v on 27.12.2016. 11 p.

12. Oleinik A. Ya. Filtration calculations of vertical drainage. Kiev: Naukova Dumka, 1978. 202 p.

13. Report on the results of the environmental impact assessment of chalk production at the site of the Hotislavskoye deposit in the Malorita district of the Brest Region. In 2 books. Book. 1. Assessment of the impact of the development of the Chotislavskoye chalk deposit (Stage II) on the hydrological and hydrogeological conditions of the adjacent territory. Ministry of Natural Resources and Environmental Protection of the Republic of Belarus. Republican Unitary Enterprise "Central Scientific Research Institute for the Integrated Use of Water Resources (RUE "TsNIIKIVR"). Minsk, 2009. 142 pp.

14. Nature of Western Polissya adjacent to Khotyslavsky's quarry in Belarus / ed. F.V. Zuzuka, Lutsk: Eastern European National University, 2014. 246 p.

15. Romashchenko M.I., Bakhmachuk Yu.Y. Formation of the natural waters regime of the Shatsk lakes district in modern conditions. Kyiv: Agrarian Science, 2004. 96 p.

16. Shestopalov V.M., Sitnikov A. B., Lyalko V. I., Pashkovsky I. S. Water exchange in hydrogeological structures of Ukraine. Methods of studying water exchange. Kiev: Naukova dumka, 1988. 267 p.

Text of the article was accepted by Editorial Team 15.03.2018

О.О. Дятел

\section{РОЗРАХУНКИ ТА ПРОГНОЗУВАННЯ ВПЛИВУ РОЗРОБКИ РОДОВИЩА «ХОТИСЛАВСЬКЕ» НА ГІДРОДИНАМІКУ ГРУНТОВИХ І ПІДЗЕМНИХ ВОД ЗАХІДНОГО ПОЛІССЯ}

Анотація. Розглянуто питання впливу розробки родовища піску та крейди «Хотиславське» на гідродинаміку грунтових і підземних вод Західного Полісся. Використано аналітичні методи розрахунку процесів геофільтрації та методи математичного моделювання. Проведено аналіз обгрунтованості прогнозних розрахунків та моделювання впливу кар'єру на територію України, виконаних білоруською стороною, та співставлення даних.

Ключові слова: область фільтрації; інфільтраційне живлення; водопритік; гідрогеологічні умови; переосушення; техногенні умови. 
Автор (науковий ступінь, вчене звання, посада):

\section{Дятел Олександр Олексійович}

науковий співробітник

Інститут водних проблем і меліорації НААН України

Адреса робоча: 03022 Україна, м. Київ, вул. Васильківська, буд. 37

ORCID ID: 0000-0002-1258-7561e-mail:alexandr_dyatel@ukr.net 